\title{
Where India stands in malaria elimination?
}

\author{
Sunil Dhiman ${ }^{* \dagger}$ and Pronobesh Chattopadhyay \\ Defence Research Laboratory, Defence R\&D Organisation, Tezpur, India \\ *Correspondence: sunildhiman81@gmail.com \\ "Scientist " $\mathrm{C}$ " \\ Edited by: \\ Souha S. Kanj, American University of Beirut Medical Center, Lebanon \\ Reviewed by: \\ Kendall A. Smith, Weill Medical College of Cornell University, USA
}

Keywords: malaria, insecticide, insecticide-treated bed nets, WHO, elimination

Malaria elimination campaign during the end of the last century relied on insecticides and malaria treatment, but this effort did not succeed in many endemic countries and collapsed after a few decades. India is among the 35 countries, which contribute $96 \%$ of total malaria cases and $98 \%$ of total malaria deaths in the world (1). Recent studies suggest that the neighboring countries of India are at the edge of eliminating malaria. In Sri lanka, the key component to achieve malaria cases reduction by $99.9 \%$ was the ability to be flexible and adapt to changing conditions $(2,3)$. Mobile malaria clinics were deployed to protect hard-toreach and displaced population groups. Long-lasting insecticide-treated nets were distributed by engaging non-governmental organizations local to the endemic areas. Bhutan has initiated the use of mobile phones to collect and map information on the location of households, breeding sites, malaria cases, and settlements $(4,5)$.

In India, the malaria control program was initiated in 1953 with an aim of eradication; however, still a number of outbreaks are occurring in different parts of the country. Recent malaria report published by National Vector Borne Diseases Control Program (NVBDCP), Ministry of Health and Family Welfare, and the government of India revealed that there were about 0.88 million confirmed malaria cases and 440 deaths attributed to malaria in 2013 (6). The overall malaria cases and deaths have decreased in recent years in India, but a study funded by NIH, USA and published in Lancet argues that more than 0.2 million
Indians die of malaria annually (7). The study further reports that about $90 \%$ of malaria related deaths were in rural areas while about $86 \%$ took place away from the health centers. A recent study has suggested that there is a certain population in India that does not have access to medical facilities for one or another reason, which further strengthen the claim that many deaths might occur at home without reaching to any reporting facility (8). The actual estimate of malaria mortality in India has been argued in recent years $(8,9)$. If the data reported in Lancet happen to be true, the substantial underreporting of malaria cases could prove to be a serious disruption of WHO's anti-malaria effort, which estimated that India is moving toward the "pre-elimination phase" by 2015 .

\section{REFERENCES}

1. Global Malaria Action Plan. Roll Back Malaria pt III-Regional Strategies. Available from: http://www. rollbackmalaria.org/gmap/part3.pdf

2. Abeyasinghe RR, Galappaththy GNL, Smith Gueye C, Kahn JG, Feachem RGA. Malaria control and elimination in Sri Lanka: documenting progress and success factors in a conflict setting. PLoS One (2012) 7:8. doi:10.1371/journal.pone. 0043162

3. Karunaweera ND, Galappaththy GNL, Wirth DF. On the road to eliminate malaria in Sri Lanka: lessons from history, challenges, gaps in knowledge and research needs. Malaria J (2014) 13:59. doi:10.1186/1475-2875-13-59

4. Tobgay T, Pem D, Dophu U, Dumre SP, NaBangchang K, Torres CE. Community-directed educational intervention for malaria elimination in Bhutan: quasi-experimental study in malaria endemic areas of Sarpang district. Malaria J (2013) 12:132. doi:10.1186/1475-2875-12-132
5. World Health Organisation. Bhutan Uses Mobile Technology to Eliminate Malaria. PAHO/WHO eHealth Newsletter. Available from: http://www. paho.org/ict4health/newsletter/eHealth_Newsletter _May13.html.

6. National Vector Borne Diseases Control. Department of Health, Ministry of Health and Family Welfare, Govt. of India. Available from: http://www. nvbdcp.gov.in/malaria-new.html

7. Dhingra N, Jha P, Sharma VP, Cohen AA, Jotkar RM, Rodriguez PS, et al. Adult and child malaria mortality in India: a nationally representative mortality survey. Lancet (2010) 376: 1768-74.

8. Shah NK, Dhariwal AC, Sonal GS, Gunasekar A, Dye C, Cibulskis R. Malaria-attributed death rates in India. Lancet (2011) 377:991-2. doi:10.1016/S01406736(11)60379-6

9. Valecha N, Staedke S, Filler S, Mpimbaza A, Greenwood B, Chandramohan D. Malaria-attributed death rates in India. Lancet (2011) 377:992-3. doi: 10.1016/S0140-6736(11)60380-2

Conflict of Interest Statement: The authors declare that the research was conducted in the absence of any commercial or financial relationships that could be construed as a potential conflict of interest.

Received: 20 June 2014; accepted: 13 July 2014; published online: 28 July 2014.

Citation: Dhiman S and Chattopadhyay P (2014) Where India stands in malaria elimination? Front. Public Health 2:98. doi: 10.3389/fpubh.2014.00098

This article was submitted to Infectious Diseases, a section of the journal Frontiers in Public Health. Copyright $\odot 2014$ Dhiman and Chattopadhyay. This is an open-access article distributed under the terms of the Creative Commons Attribution License (CC BY). The use, distribution or reproduction in other forums is permitted, provided the original author(s) or licensor are credited and that the original publication in this journal is cited, in accordance with accepted academic practice. No use, distribution or reproduction is permitted which does not comply with these terms. 